\begin{tabular}{|c|c|c|c|c|c|c|}
\hline \multirow{4}{*}{ Impact Factor: } & ISRA (India) & $=3.117$ & SIS (USA) & $=0.912$ & ICV (Poland) & $=6.630$ \\
\hline & ISI (Dubai, UAF & $=0.829$ & РИНЦ (Russia) & $=0.156$ & PIF (India) & $=1.940$ \\
\hline & GIF (Australia) & $=0.564$ & ESJI (KZ) & $=8.716$ & IBI (India) & $=4.260$ \\
\hline & JIF & $=1.500$ & SJIF (Morocco) & $=5.667$ & OAJI (USA) & $=0.350$ \\
\hline
\end{tabular}

\section{SOI: $1.1 /$ TAS $\quad$ DOI: $10.15863 /$ TAS \\ International Scientific Journal Theoretical \& Applied Science}

p-ISSN: 2308-4944 (print) e-ISSN: 2409-0085 (online)

Year: 2019 Issue: 07 Volume: 75

Published: $08.07 .2019 \quad \underline{\text { http://T-Science.org }}$
QR - Issue

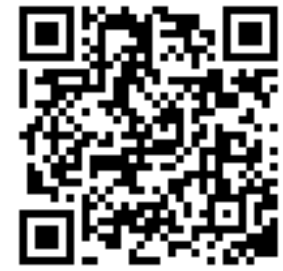

QR - Article

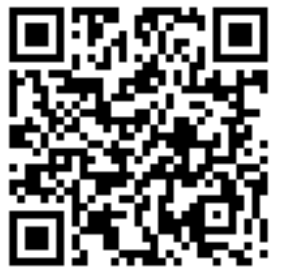

Flyura Kholboyevna Nurdinova Andizhan State University

Senior teacher of the chair of Theory of civil society, Republic of Uzbekistan

\title{
THE CRITERION FOR INCREASING THE POLITICAL PARTICIPATION OF WOMEN IN THE WORK OF CIVIL SOCIETY INSTITUTIONS
}

\author{
Abstract: This article examines the role and place of civil society institutions in Uzbekistan in increasing the \\ socio-political activity of women. \\ Key words: civil society, legal culture, women's activism, non-governmental non-commercial organizations, \\ community unions. \\ Language: English \\ Citation: Nurdinova, F. K. (2019). The criterion for increasing the political participation of women in the work \\ of civil society institutions. ISJ Theoretical \& Applied Science, 07 (75), $50-52$. \\ Soi: http://s-o-i.org/1.1/TAS-07-75-10 Doi: crossef https://dx.doi.org/10.15863/TAS.2019.07.75.10 \\ Classifiers: Policy. Innovations. Theory, practice and methods.
}

\section{Introduction.}

The process of strengthening the independence of Uzbekistan, its socio-economic development, the establishment of a democratic democratic state based on a free market economy and civil society is directly related to the Law "On Public Associations in the Republic of Uzbekistan", adopted by the Supreme Council of Uzbekistan on February 15, 1991. "For the first time in the history of the country, the independence of civil society institutions and public associations has been recognized as a legal entity acting separately from government and government" $[1$, p.42]. Particularly, the Constitution of the Republic of Uzbekistan provides the basic principles for the non-governmental and non-profit associations, and creates favorable conditions for the development of a wide range of organizations that represent the interests of all segments of the population. In this process, the issue of political and legal culture and socio-political activeness of women constitutes more than half of the country's population. The liberalization of the state and society in all sectors of the political sphere and raising the political activity of the population is one of the main tasks of forming a political culture based on national and universal values. "Civil society institutions, nongovernmental nonprofit organizations are now becoming an important factor in protecting the democratic values, human rights and freedoms and legitimate interests, creating conditions for the realization of their potential, their social, social and economic activity and legal culture, helping to balance [2.-p.6].

Indeed, today we have been targeted at building a civil society by introducing the concept of "from a strong state to stronger society" to the development of the developed countries, whilst fully overseeing human rights and interests, creating a free and prosperous life. In this regard, it is the time of deepening democratic reforms and modernization of the country, primarily aimed at improving the state and society building. Further improvement of the role of executive power in reforming and modernizing the public administration system has become a necessity to develop a concept of administrative reform to regulate democratic reforms in a society [3, p.34].

President of the Republic of Uzbekistan Sh. Mirziyayev, the "Strategy for Action on the Development of the Republic of Uzbekistan for 20172021" adopted on February 7, 2017, is primarily aimed at this goal. Part 4 of the Action Strategy focuses on the priorities of social development, including the promotion of women 's socio - political activity, their role in government and public administration, the employment of graduates of 


\begin{tabular}{|c|c|c|c|c|c|c|}
\hline \multirow{4}{*}{ Impact Factor: } & ISRA (India) & $=3.117$ & SIS (USA) & $=0.912$ & ICV (Poland) & $=6.630$ \\
\hline & ISI (Dubai, UAE & $=0.829$ & РИНЦ (Russia & $=0.156$ & PIF (India) & $=1.940$ \\
\hline & GIF (Australia) & $=0.564$ & ESJI (KZ) & $=8.716$ & IBI (India) & $=4.260$ \\
\hline & JIF & $=1.500$ & SJIF (Morocco & $=5.667$ & OAJI (USA) & $=0.350$ \\
\hline
\end{tabular}

women's and professional colleges, focusing on the broader involvement, the further strengthening of family foundations.The role of civil society institutions in the successful implementation of the above issues is immeasurable.

In Uzbekistan, extensive work is being carried out to ensure organizational and legal conditions, economic and legal guarantees for the formation of non-profit and public organizations during active democratic renewals and modernization of the country, and to ensure their active participation in society. The Law of the Republic of Uzbekistan "On non - governmental and non - commercial organizations" and the joint resolution of the Councils of both chambers of the Oliy Majlis of the Republic of Uzbekistan "On measures to strengthen the support of non - governmental and non - commercial organizations, other civil society institutions" serves as an important legal basis. These documents are aimed at the development of public organizations in the country, strengthening their material and technical base, strengthening the role of public organizations in raising women's socio - political activity, their active participation in the socio - political life of the country, and the broader access to women' and attracts them [4, p.65].

At present more than 9000 NGOs and more than 200 non-profit organizations are operating in Uzbekistan. Many of them work in areas such as women's legal and economic education, support and development of entrepreneurship, women' s health, protection of women 's knowledge and skills, and moral support. Particular attention is paid to the consistent development of non-profit non-profit and public organizations as an essential condition for increasing women's socio-political activity [5, p.23].

In particular, the basis of social activity is the political and legal culture of the person. It is impossible to become involved in organizing and managing a community without knowing which goals and mechanisms it is based on. Social activity is, in essence, a voluntary, collective action that moves people for free time. In society, non-governmental and self-governing bodies are the institutions for organizing people's social activities. It was their political and legal activity in organizational activities [6].

One of the key features of civil society is the free functioning of democratic institutions based on high legal and political culture and their equitable relationship with government agencies. "Let these institutions and organizations have a decent place in the decision-making system, the protection of the interests of the social groups and structures they represent." In this sense, the establishment of partnerships with non-governmental non-profit organizations with local authorities is now important in the socio-political life of society. In particular, the Law "On Social Partnership", adopted in 2014, was the main stage in the implementation of social partnership in the country. The social partnership is the cooperation of state bodies and other civil society institutions with the implementation of socioeconomic development programs of the country, including the implementation of network, legal programs, as well as other legal acts and other decisions concerning rights and legitimate interests of citizens [7].

Nowadays, the main objective of implementing social partnerships in Uzbekistan is the implementation of social partnerships in the implementation of major social projects among state and civil society, which leads to the state's being strong, sustainable and effective, since it is widely accepted by the public, , which provides support.

In recent years, the Decree of the President of the Republic of Uzbekistan "On Measures to Support the Development of Civil Society Institutions in Uzbekistan" and other documents have been adopted, including the Laws "On Public Funds", "On Funding", and the role of an important factor in strengthening the social activity of civil society institutions doing it.

Socio - political activity is an important concept which covers a wide and diverse range of activities. This activity is not a government-oriented act, but rather a behavioral act aimed at managing the lives of the community. Non-governmental non-profit organizations and public associations of women in the Republic of Uzbekistan have become part of social life of society, but have not yet become a social movement that can influence the most important events. Because their lack of co-operation with government agencies has a negative impact on the activities of these organizations. At the same time, as President of the Republic of Uzbekistan Shavkat Mirziyayev noted in his appeal to the Oliy Majlis on 29 December 2018, "it is a pity that there are still more than 13,000 women who are in difficult life in the country and are not employed".

It is delighted to see a growing share of women among many public organizations in Uzbekistan, including among political parties and their structures, particularly among elected members. For example: currently in the Senate\% of the Senate, $\%$ of the Legislative Chamber. However, there is another aspect of the matter: not only political parties should strive for women. Political parties should seek a thorough investigation into the building of a democratic state and civil society to raise women's legal literacy in addressing the issues related to entrepreneurship, to further advocacy and propaganda among women, and to build leadership capacities. At the same time, "Women's Wing" of political parties is working on this issue. In particular, various social projects, grant programs, practical workshops, contests, roundtables have been instrumental in promoting women's active participation in society. "The further strengthening of the role of non-state 


\begin{tabular}{|c|c|c|c|c|c|c|}
\hline \multirow{4}{*}{ Impact Factor: } & ISRA (India) & $=3.117$ & SIS (USA) & $=0.912$ & ICV (Poland) & $=6.630$ \\
\hline & ISI (Dubai, UAE & $=0.829$ & РИНЦ (Russia & $=0.156$ & PIF (India) & $=1.940$ \\
\hline & GIF (Australia) & $=0.564$ & ESJI (KZ) & $=8.716$ & IBI (India) & $=4.260$ \\
\hline & JIF & $=1.500$ & SJIF (Morocco & $=5.667$ & OAJI (USA) & $=0.350$ \\
\hline
\end{tabular}

non-profit organizations and other civil society institutions at the current stage of the development of the country is an indispensable factor in the achievement of the set goals set forth for the formation, democratization and integration of our country into the international community, and it is unnecessary".

As long as the society has undergone radical changes, civil society institutions can not stay away from these processes. In that sense they must contribute to the elimination of society's problems "[8.15].

The following points and conclusions can be summarized as follows:

1. The role of women in the activities of nongovernmental non-profit organizations and public associations plays an important role in supporting and encouraging members, enhancing their socio-political activity, and enhancing their knowledge and skills. It plays a major role in building a democratic state and civil society [9].

2. NGOs and public associations aimed at protecting the interests of women are aimed at ensuring the socio-political, economic interests, interests and interests of women, who constitute the vast majority of the population. Their socio-political, psychological and spiritual impact is of paramount importance,

3. In implementing the concept of transition from a strong state to a strong civil society in our social life, it is desirable for civil society institutions, NGOs and public associations to carry out many social projects that express their interests, interests and needs.

4. It is important to emphasize that the role and place of the media in the promotion of NGOs aimed at protecting women's interests is also important today.

It is necessary to say today President Shavkat Mirziyayev's initiatives are being carried out by the Presidential Councils of the Republic of Uzbekistan in all regions of the Republic to hear about the challenges and problems of the 33 million people of Uzbekistan. In addition, the electronic communication service has been established and the Presidential Party is functioning. On the basis of the idea that "public institutions should serve the public, not the public," the focus is on improving the performance of public administration in order to increase the effectiveness of public services in the country, and administrative reform is being carried out [10]. In turn, the goal of the administrative reform is to improve the public service delivery system and to elevate the public administration system to a new level, taking into account the interests of all segments of the population.

\section{In conclusion.}

Women's movement has a great potential in the functioning of civil society institutions operating in Uzbekistan. They combine their strength to protect women's rights, actively participate in democratic processes in the country, and achieve gender equality, with their work creating a foundation for the future generations.

\section{References:}

1. Karimov, I. A. (2010). Concession of further deepening of democratic reforms and formation of civil society in the country. (p.42). Tashkent: Uzbekistan.

2. Karimov, I. A. (2004). Peace and security depends on our strength, our unity and solid will. Collection of works. Volume XII: Uzbekistan.

3. Qirgyzboev, M. (n.d.). Civil society: gene formation, formation and development.

4. (2000). Women's Resource Center. (p.6). Tashkent.

5. (2000). Female Resource Center. (p.3). Tashkent.
6. (2000). Women's Resource Center. (pp.6-8). Tashkent.

7. (2000). Female Resource Center. (pp.6-8). Tashkent.

8. (2000). Women's Resource Center. (pp.6-8). Tashkent.

9. (n.d.). Removed from the report of the NGO "Sabr" of the city of Samarkand.

10. Yunusov, K. A., et al. (2011). Prospects for the Creation and Development of Civil Society Institutions in Uzbekistan. Tashkent: Sharq. 